ОВчИННИКОВ Александр Викторович - кандидат исторических наук; научный сотрудник лаборатории трансдисииплинарных исследований познания, языка и социальных практик философского факультета Национального исследовательского Томского государственного университета (634050, Россия, г. Томск, пр-кт Ленина, 36; ovchinnikov8_831@таil.ru)

ЕРШОВА Гузель Николаевна - кандидат исторических наук; преподаватель кафедры государственного, муниципального управления и социологии Казанского национального исследовательского технологического университета (420015, Россия, Республика Татарстан, г. Казань, ул. К. Маркса, 68; ershova104@таil.ru)

\title{
1552 ГОД В СЕТЕВОМ СООБЩЕСТВЕ TAТАРСТАНА: СОЦИАЛЬНЫЕ И ПОЛИТИЧЕСКИЕ АСПЕКТЫ ВЕРСИЙ ИСТОРИЧЕСКОЙ ТРАВМЫ
}

\begin{abstract}
Аннотация. Актуальность темы обусловлена необходимостью сбора эмпирического материала для философского осмысления проблемы «исторических травм», а также практической важностью анализа конструктов, противостоящих образам общероссийской идентичности. Объект исследования - современный татарский этнонационализм, предмет - осмысление в его рамках захвата Казани Иваном IV в 1552 г. В исследовании использовались характерные для социально-культурной антропологии методы наблюдения, включенного эксперимента и насыщенного описания. Научная новизна работы заключается в попытке анализа социальных и политических аспектов версий «исторической травмы» 1552 года.
\end{abstract}

Ключевые слова: взятие Казани, День памяти, Иван IV, историческая травма, освободительная война татарского народа, татарский этнонационализм

$\mathrm{C}$

тановление общероссийской идентичности - важнейшая проблема национальной безопасности государства. Современная Россия унаследовала от СССР административно-территориальное деление, некоторые элементы которого основаны на диффузии этнического и государственного. Речь, прежде всего, идет о так называемых национальных республиках, которые в официальных документах атрибутируются как «государства», одним из элементов «государственности» которых являются собственные исторические нарративы. Эти повествования о прошлом часто выступают конкурентами общефедеральной истории, в их рамках конструируются цепочки государств-предшественников, отличные от официально принятого канона (Киевская Русь - Московская Русь - Российская империя - СССР - Российская Федерация). Более того, в исторических сюжетах «свои» государства часто выступают противниками государственных предшественников России. Например, в современном Татарстане, благодаря усилиям региональных политических и интеллектуальных элит, СМИ и системе образования, создан впечатляющий нарратив об истории государственности «татарского мира», в котором присутствуют образы Волжской Булгарии - соперницы Киевской Руси в Восточной Европе в IX-XIII вв., Золотой Орды - покорительницы русских княжеств и Московской Руси в XIII-XIV вв. и, наконец, Казанского ханства, захват которого в 1552 г. якобы прекратил поступательное развитие татарской государственности, «возрожденной» в ограниченных рамках только в 1920 г. в виде Татарской Автономной Советской Социалистической Республики. Образу 1552 г. принадлежит ключевая роль в региональном историческом нарративе, а его регулярная актуализация, наполнение эмоциональным содержанием, роль разделительного маркера 
для «своих» и «чужих» дают полное основание отнести представления о 1552 г. к категории «исторических травм».

Trauma studies - динамично развивающаяся междисциплинарная область социально-гуманитарных наук. Выполненные в этом жанре работы позволяют понять психологические, политические, историософские аспекты повышенного и не всегда адекватного внимания современников к событиям часто далекого прошлого, нюансы конструирования этого внимания, трансляции эмоционально окрашенных образов в массовое сознание, инструментальное использование результатов пропаганды исторических травм [Айерман 2013; Александер 2012; Мороз, Суверина 2014; Ушакин 2009; Николаи 2018; Сафронова 2019].

Отличительной особенностью «травмы 1552 г.» является ее активное использование как в политической борьбе, так и в публичных диспутах интеллектуалов, что обусловило формирование к настоящему времени значительного корпуса источников: материалов официальных документов, СМИ, учебных и академических текстов, художественных произведений. Однако наибольшей продуктивности при изучении «травмы 1552 г.» можно достичь при условии ее изучения в рамках сетевого сообщества, т.к., во-первых, почти все вышеназванные источники циркулируют в интернет-среде, во-вторых, появляется возможность зафиксировать «социальную жизнь» исторической травмы в виде лайков, репостов, комментариев, состава групп в социальных сетях и т.д.

Предварительный обзор источников и политической истории Татарстана с 1990 (объявление суверенитета) до 2019 г. дает основание утверждать, что существуют две версии «травмы 1552 г.» - радикальная и компромиссная, и они активно используются в политических целях. Радикальная версия характеризуется однозначно негативными оценками последствий взятия Казани Иваном IV и однозначным «рецептом восстановления исторической справедливости» это получение Татарстаном полной независимости, превращение его в «татарское государство». Данная версия была востребована местными радикальными националистическими общественными объединениями и примерно до 1994 г. была «политически выгодна» руководству Татарстана, которое вело непростые переговоры с федеральным центром о контроле над экономическим потенциалом региона. После подписания в 1994 г. Договора о разграничении полномочий и предметов ведения между Республикой Татарстан и Российской Федерацией радикальная версия «травмы 1552 г.» стала постепенно, вместе с ее носителями, маргинализироваться, а в политическом тренде оказалась компромиссная версия «травмы 1552 г.». Суть данной версии заключается в констатации как положительных, так и негативных последствий «казанского взятия»; ее носителями выступают респектабельные «системные» политики, академические ученые, журналисты ${ }^{1}$.

Судя по содержанию наиболее популярных в сети Интернет учебных курсов и обобщающих академических изданий, именно компромиссная версия «травмы 1552 г.» ложится в основу периодизации всего материала. Например, изложение в ставшем классическим и переиздаваемом в разных формах школьном учебнике Р.Г. Фахрутдинова (1937-2014) «История татарского народа и Татарстана» заканчивается захватом Казани войсками Ивана IV и очерком по истории постордынских государств, которые, в конце концов, стали частью Российского государства [Фахрутдинов 2000: 225-249]. В используемой в качестве учебного пособия для вузов книге академика АН РТ И.Р. Тагирова «История

1 Искандер Гилязов: «Мы что - должны 450 лет лить слезы, что потеряли свое государство?» - «БИЗНЕС Online». 14.01.2018. Доступ: https://www.business-gazeta.ru/ article/369829 (проверено 11.07.2020). 
национальной государственности татарского народа и Татарстана» принципиально оставлена лакуна между 1552 и 1917 гг., т.к. с момента взятия Казани до установления советской власти у татар не было «собственного государства» [Тагиров 2008]. В обобщающем 7-томном академическом труде «История татар» 1552 г. стал водоразделом между 4-м и 5-м томами. Примечательно, что 4-й том назывался «Татарские государства XV-XVIII вв.», а 5-й - «Татарский народ в составе Российского государства (вторая половина XVI-XVIII вв.)». Сотрудник Института истории АН РТ А.Г. Галлямова отмечала: «...конвенциональным условием периодизации многотомника является достигнутый татарским народом уровень государственности» [Галлямова 2009: 141]. Даже в компромиссной версии «травмы 1552 г.» повышенное внимание к «казанскому взятию» связано с негативными коннотациями «потери» «родного» государства, его разрушения «другим» государством, причем этот конструкт по умолчанию переносится на отношения Татарстана с федеральным центром.

Возможность использования исторической «травмы 1552 г.» в политической коммуникации является главной причиной последовательной и систематической актуализации событий 468-летней давности. Интересным примером здесь служит переизданный в 2015 г. Татарским книжным издательством в форме монографии упоминавшийся школьный учебник Р.Г. Фахрутдинова. В новом издании к описанию событий 1552 г. было добавлено утверждение об «аннексии» Казанского ханства [Фахрутдинов, Фахрутдинов 2015: 136], что в условиях начавшейся после присоединения в 2014 г. к России Крыма (территории бывшего татарского Крымского ханства) информационной войны звучало с вполне определенной политической направленностью. Однако в следующем издании, датированном 2018 г. и выпущенном тем же издательством, слово «аннексия» заменено на «захват» [Фахрутдинов 2018: 92]. Таким образом, конкретное практическое применение исторической травмы выражается в степени инструментального использования или, наоборот, неиспользования ее негативного эмоционального потенциала, что и позволяет говорить о радикальной и компромиссной версиях трактовки «травмы 1552 г.».

Нечеткое разделение в доступных источниках двух версий травмы определенным образом связано с динамикой социального положения основных акторов конструирования образа 1552 г. Авторы этих строк в ряде работ предпринимали попытки показать, что историческая травма 1552 г., видимо, отражает психологические переживания интеллектуалов и деятелей культуры, которые являются выходцами из села или горожанами в первом поколении [Васина, Овчинников 2019; Овчинников 2019]. По данным Л.В. Сагитовой, в 1970-х гг. 3/4 работников умственного труда в ТАССР были выходцами из села и горожанами в первом поколении, в 1990-х гг. научная и творческая интеллигенция на 60,7\% была представлена выходцами из села, 39,3\% составляли горожане [Сагитова 2019: 143]. В воспоминаниях крупных историков Татарстана, активно пишущих на тему 1552 г., обычными являются сюжеты о «золотом веке» жизни в деревне с родителями, переезде на учебу в Казань, начальном этапе освоения (отвоевания) неприветливого города посредством жизни в общежитиях, на съемных квартирах, поступлении на работу в учебное или академическое учреждение и, наконец, заветном моменте получения городской квартиры ${ }^{1}$ [Тагиров 2016: 35].

Осторожные суждения в рамках компромиссной версии «травмы 1552 г.» ведут уже укоренившиеся в городе вчерашние сельчане, имеющие жилье и стабильную работу, чьи ставшие взрослыми дети нередко пошли по проторенному

1 Дамир Мавлявеевич Исхаков: биобиблиографический указатель. К 60-летию со дня рождения и 40-летию научной деятельности (отв. ред. И.Л. Измайлов). 2011. Казань. С. $7,17$. 
ими академическому пути или сделавшие карьеру в иных сферах (показательным примером восходящей социальной мобильности является жизненный путь сына доктора исторических наук, заведующего отделом Новой истории Института истории АН РТ И.К. Загидуллина ${ }^{1}-$ Р.И. Загидуллина, родившегося в Казани, окончившего престижный юридический факультет местного классического университета и ставшего в 2017 г. министром юстиции Татарстана) ${ }^{2}$.

Радикальная версия травмы 1552 г. привлекает молодежь - недавно приехавших из села учиться в казанских вузах студентов, стремящихся самоутвердиться посредством политической активности. Например, лидер татарской националистической организации Союз татарской молодежи «Азатлык» («Свобода») Наиль Набиуллин ${ }^{3}$ в интервью одному из авторов этих строк (А.В. Овчинникову) обрисовал свой путь из деревни в город, рассказав об «открытии истинной истории татар», трудностях жилищного вопроса, стремлении во что бы то ни стало исправить «несправедливости 1552 г.», о невозможности устроиться на работу из-за организации митингов (в т.Ч. посвященных памяти о захвате Казани Иваном IV), преследованиях властей и т.д. Другой пример: студентка одного из казанских колледжей 3.Н. - родом из Аксубаевского района Татарстана, ее родители - известные в районе деятели культуры. 3.Н. интеллектуально развита, активно участвует в деятельности популярного молодежного центра «Сэлэт», мероприятиях Всемирного конгресса татар (например, флешмобах в «защиту» татарского языка), подрабатывает фотографом в структурах этой организации. 3.Н. занимается студенческой наукой, особо интересуется историей Татарстана. Однажды в рамках подготовки студенческого проекта по сохранению культурного наследия Татарстана она предложила идею распространения мультфильмов на татарском языке. Конечным пунктом реализации «мультипликационного проекта» значилась по-детски наивная и откровенная цель - «выход Татарстана из состава Российской Федерации, обретение им полной независимости» (полевые материалы А.В. Овчинникова).

Кроме молодежи, в дискурсе радикальной версии «травмы 1552 г.» ведут риторику авторы, не имеющие, в отличие от своих «компромиссных» коллег, доступа к символическим и материальным ресурсам, и надолго оказавшиеся «посередине» урбанизационного пути. Примером этого является прошедшая в 2009-2010 гг. дискуссия вокруг книги казанского автора, кандидата исторических наук Н. Гарифа «Освободительная война татарского народа». Нурулла Гариф родился в 1960 г. в деревне Яна Сала Рыбнослободского района Татарстана. Окончил физический факультет Казанского государственного университета им. В.И. Ленина. В 2006 г. защитил кандидатскую диссертацию в Диссертационном совете при Институте истории им. Ш. Марджани АН PT ${ }^{4}$. На момент дискуссии работал учителем в сельской школе.

Нашумевшая книга Н. Гарифа была издана в 2007 г. государственным Татарским книжным издательством, носила популярный характер, содержала яркие иллюстрации и в книжных магазинах часто находилась в отделах детской литературы. Начиналось повествование характерным для мотива исторической

1 Загидуллин Ильдус Котдусович. - Институт истории им. Ш. Марджани АН РТ. Доступ: http://татаровед.pф/departments/2/employees/39 (проверено 11.07.2020).

2 Загидуллин Рустем Ильдусович. - Министерство юстиции Республики Татарстан. Доступ: http://minjust.tatarstan.ru/rus/rukov/minister.htm (проверено 11.07.2020).

3 Татарский активист Наиль Набиуллин посвятил свой пробег до Болгар юбилею Золотой Орды. - БИЗНЕС Online. 04.07.2019. Доступ: https://www.business-gazeta.ru/ news/430445 (проверено 11.07.2020).

4 Нурулла Гариф. - Википедия. Доступ: https://tt.wikipedia.org/wiki/Нурулла_Гариф (проверено 11.07.2020). 
травмы утверждением, что «в жизни каждого народа бывают памятные даты, связанные с теми или иными, порой драматичными, историческими событиями, переломными моментами, на долгие годы, века вперед предопределившими направление их дальнейшего бытия и развития. Прочно закрепившись в народной памяти, такие даты становятся частичкой национального самосознания» [Гариф 2007: 2].

Нарратив «Освободительной войны...» содержал типичные для мифа построения. «Золотой век» истории татар заканчивался в 1552 г. с приходом «русских оккупационных отрядов» и «карателей» [Гариф 2007: 26, 27]. Далее наступало время «хаоса». Н. Гариф красочно описывал ужасы взятия Казани, причем врагом безапелляционно выступали «русское государство» и «русские». Автор давал понять, что Казанское ханство присоединено нелегитимно, само завоевание представлялось как покорение одного народа другим. Здесь опять же уместно отметить характерную для татарского этнонационализма связь этничности и государственности: «Русские считали, что окончательно завоевали Казанское ханство, и приступили к выполнению своих административных обязанностей» [Гариф 2007: 24].

Иллюстративный ряд книги содержал визуальные ряды негативных образов «казанского взятия» и дальнейшего нахождения татар в составе Российского государства. В ярких картинках православные символы противопоставлялись мусульманским [Гариф 2007: 18, 19, 47]. На иллюстрации «Шамаиль “1552 год”» была изображена вылетающая из черных туч черная двуглавая птица, напоминавшая двуглавого орла российского герба и направляюшаяся на башню Сююмбике, служащую символом защиты Казани в 1552 г. (хотя башня была построена только в XVII в.) [Гариф 2007: 69].

Судя по красовавшейся на обложке книги эмблеме, один из эпизодов «освободительной войны» Н. Гариф видел в созданном немецким командованием в годы Великой Отечественной войны легионе «Идель-Урал» в составе вермахта, состоявшем из представителей поволжских народов (в основном татар).

В одном из последних пассажей повествования утверждалось, что «несмотря на неимоверные испытания, которые пришлось выдержать татарскому народу, начиная с 1552 года, он смог сохраниться, остался несломленным и гордым» [Гариф 2007: 66]. Таким образом, завоевание Казани и последующие невзгоды в воображении автора выступали для народа - главного «героя» книги - некими инициациями, которые тот вынужден был пройти после конца «золотого века». Выживший герой стремится преодолеть «хаос» и вернуть прежний «легитимный» порядок вещей, что можно понять из следующих строк: «Борьба за восстановление независимого государства продолжается и в наши дни» [Гариф 2007: 66].

Стоимость издания с качественной полиграфией составляла в 2009 г. всего 30 руб., что вызывало ассоциации с дешевой пропагандистской литературой советского времени (на подобной продукции тогда Таткнигоиздат в основном и специализировался).

В 2009 г. на «Освободительную войну татарского народа» было публично обращено внимание прокуратуры Татарстана, что послужило поводом для многочисленных публикаций в СМИ и полемики в Интернете. Сигналом к общероссийскому резонансу послужила вышедшая 6 августа 2009 г. статья Я. Сташкевича «Казанское ханство продолжает борьбу за независимость» ${ }^{1} .19$ августа 2009 г. в «Независимой газете» была опубликована статья Я. Гордеева «Продолжение

1 Сташкевич Я. Казанское ханство продолжает войну за независимость. 06.08.2009. Доступ: https://svpressa.ru/all/article/12268/ (проверено 11.07.2020). 
“татарской освободительной войны”»1. Информация о конфликте вокруг произведения Н. Гарифа появилась в новостных выпусках радио «Эхо Москвы». Казанская телерадиокомпания «Эфир» сняла соответствующий сюжет. 21 августа 2009 г. свое видение проблемы высказало радио «Азатлык» (подразделение радиокорпорации «Свобода») $)^{2}$.

Наивысшей точки конфликт достиг в конце сентября - начале октября 2009 г., когда шла подготовка к проведению специального круглого стола по вопросу книги Н. Гарифа. Организатором диспута выступил Центр евразийских и международных исследований Казанского государственного университета им. В.И. Ульянова-Ленина. Изъявили желание прийти поддержать автора «Освободительной войны...» сотрудники Института истории АН РТ А.А. Бурханов (к.и.н.), Р.Ф. Галлям (к.и.н.), И.К. Загидуллин (д.и.н.), Б.И. Измайлов (к.и.н.), И.Л. Измайлов (к.и.н.), Д.М. Исхаков (д.и.н.), Ф.М. Султанов (д.филос.н.), Ф.Ш. Хузин (д.и.н.) и др. За несколько месяцев до этого Институт истории провел две экспертизы «Освободительной войны...», но его сотрудники не нашли в книге своего бывшего аспиранта ничего предосудительного, а только изложение исторических фактов [Загидуллин, Галлям 2009; Измайлов, Бушуев, Салихов 2009].

Предстоящий круглый стол вызывал оживленный интерес, были аккредитованы многие СМИ: ИА «Татар-информ», ИА «Росбалт», радио «Азатлык», телерадиокомпания «Татарстан - новый век» (ТНВ), газеты «Звезда Поволжья», «Новая газета», «Независимая газета», «Ватаным Татарстан», «Вечерняя Казань», «Известия Татарстана», «Честное слово», «Казанские ведомости», «Республика Татарстан», «Евразийские горизонты», «Диалог-Евразия», «Тархан», «Шэһри Казан», «Казанские истории». Организаторы диспута наметили его проведение на 7 октября 2009 г., тогда как на 11 октября татарскими националистами было запланировано проведение митинга, посвященного Дню памяти защитников Казани от войск Ивана IV. По понятным причинам по негласной инициативе властей региона круглый стол в итоге был отменен. После этого накал полемики пошел на спад. Официально книга не была изъята из продажи, но в реальности под предлогом того, что ее раскупили, она исчезла с прилавков книжных магазинов.

Дискуссия вокруг книги Н. Гарифа, энергичные поддержка и оправдание его со стороны местного академического института и региональных властей высветили проблему зыбкой границы между радикальным и умеренным татарским этнонационализмом и, соответственно, радикальной и компромиссной версиями исторической травмы 1552 г.

Репрезентативным источником для изучения радикальной версии данной травмы является опубликованное в 2013 г. на сайте газеты «Звезда Поволжья» и посвященное очередной годовщине взятия Казани обращение крайне правых татарских националистов, представлявших Набережно-Челнинское отделение Татарского общественного центра ${ }^{3}$ (в 2017 г. организация признана экстремистской, а ее деятельность на территории России запрещена) ${ }^{4}$. Название публика-

1 Гордеев Я. Продолжение «татарской освободительной войны». 19.08.2009 Доступ: http://www.ng.ru/regions/2009-08-19/1_book.html (проверено 11.07.2020).

2 Нурулла Гариф: Тарихтан биздерү гасырлар буе бара. - Радио «Азатлык» 21.08.2018. Доступ: http://www.azatliq.org/content/article/1804773.html (проверено 11.07.2020).

312 октября в Казани - День памяти татарского народа! 25.10.2013. Доступ: http://zvezdapovolzhya.ru/obshestvo/12-oktyabrya-v-kazani-den-pamyati-tatarskogonaroda-25-10-2013.html (проверено 11.07.2020).

4 Деятельность ТОЦ в Набережных Челнах прекращена, организация признана экстремистской. 11.05.2017. Доступ: https://www.business-gazeta.ru/news/345560 (проверено 11.07.2020). 
ции носило концептуальный характер, т.к. в ней 12 октября объявлено Днем памяти татарского народа. Авторы пытались объяснить, почему дата падения Казани отмечается именно как День памяти. Судя по тексту, это прежде всего память о разграблении и разрушении Казани, устроенной там резне. Войска Ивана IV названы «оккупантами». После исторического экскурса авторы обращаются к властям и общественности с рядом предложений. Так, российскому руководству предлагается принести извинения поволжским народам «за варварское завоевание» в 1552 г. и предоставить им все права «коренных народов». Далее предлагается внести изменения в школьную программу и издать соответствующие учебники с тем, чтобы «прекратить пропаганду ложной, вымышленной истории Москвы», и официально отразить День памяти в государственном календаре Татарстана. Затем следуют инициативы, связанные с организационными аспектами проведения Дня памяти. От глав администраций районов и городов Татарстана требуется оказывать помощь желающим участвовать в мероприятии в организации поездки в Казань, а СМИ предлагается широко освещать это событие. Апелляция к государственным структурам соседствует с обращением к мусульманским религиозным деятелям: имамам Татарстана перед Днем памяти рекомендуется совершать пятничные намазы «в честь защитников Казани 1552 г.» И наконец, татарам всего мира предлагается отмечать День памяти, «используя для этого мечети, медресе, школы, иные учебные заведения и любую другую возможность». Проекты глобального масштаба чередуются с более актуальными в политическом отношении вопросами. Например, историкам предлагается провести конференцию по поводу «сталинского» фильма «Иван Грозный» и современного фильма «Орда» 1 .

Сам факт такого обращения свидетельствует об инструментальном использовании мифа исторической травмы и в то же время иллюстрирует слабые логические связи внутри мифических конструкций, в которых абстрактные понятия по большей части заменены конкретно-чувственными образами с ярко выраженным эмоциональным содержанием.

Текст обращения конструирует особый хронотоп, который является альтернативой тому времени, которое государством и обществом признается как «современное» и «реальное». Например, вряд ли нынешнее российское правительство в юридическом смысле этого слова является правопреемником Боярской думы времен Ивана IV и может приносить некие «извинения» за действия последнего.

Стремление изменить школьные учебники истории свидетельствует о попытке «перекройки» официального, усвоенного большинством населения с детского возраста хронотопа. Предлагается новый исторический нарратив, благодаря которому «настоящее» может восприниматься совершенно другим образом. Современное российское государство отождествляется авторами обращения с негативными для татар страницами прошлого, благодаря чему якобы лишается своей исторической легитимности.

Попытка изменить реальное время, сделать его удобным полем для собственной политической игры осуществляется через основанные на интерпретации событий 1552 г. предложения по конкретным действиям в настоящем. Авторы обращения апеллируют к агентам, ответное действие или бездействие которых создают символическое поле политической коммуникации. Ее осмысление приобретает статус «современной политической истории». Интересно отметить, что в обращении все «ответчики» обезличены («власти России и Татарстана», «СМИ Татарстана», «татары всего мира», «татарские ученые-исто-

112 октября в Казани - День памяти татарского народа! 25.10.2013. 
рики», «имамы всех мечетей»). Отсутствие реакции с их стороны позволяет наделять определенными характеристиками конкретных людей, ассоциируемых с теми или иными этническими, социальными, политическими и религиозными группами, и, соответственно, вовлекать их в эмоциональный дискурс исторической травмы.

Подводя промежуточные итоги исследования, следует констатировать, что эмоциональное содержание образа исторической травмы 1552 г. негативно сказывается на конструировании общероссийской идентичности, т.к. является своеобразной точкой бифуркации, которая разделяет общее прошлое россиян, делегитимирует современную российскую государственность и может служить потенциальным поводом для конфликта. «Жизненную силу» обеим версиям исторической травмы 1552 г. придают возможности их инструментального использования в политических целях и, в конечном итоге, преобладание в отечественной интеллектуальной среде и обыденном сознании примордиальных этнонационалистических мировоззренческих представлений.

Статья опубликована при финансовой поддержке Российского научного фонда, проект № 17-78-20149 в рамках работы Школы молодого этнополитолога в Республике Башкортостан.

\section{Список литературы}

Айерман Р. 2013. Социальная теория и травма. - Социологическое обозрение. T. 12. № 1. С. 121-138.

Александер Дж. 2012. Культурная травма и коллективная идентичность. Социологический журнал. № 3. С. 5-40.

Васина В.В., Овчинников А.В. 2019. Проблема исторической детравматизации этнического сознания (постановка проблемы). - «Прошлое»: теория и практика (де)конструирования в научном и политическом дискурсах: материалы всероссийской с международным участием научно-практической конференции. Казань, 22-23 ноября 2019 г. Казань: Изд-во «Познание» Казанского инновационного университета. С. 341-347.

Галлямова А.Г. 2009. История татар и Татарстана в дискурсе советской эпохи. - Национальная история татар: теоретико-методологическое введение. Казань: Институт истории им. Ш. Марджани АН РТ. С. 138-163.

Гариф Н. 2007. Освободительная война татарского народа. Казань: Татарское книжное издательство. $71 \mathrm{c.}$

Загидуллин И.К., Галлям Р.Ф. 2009. Рецензия на книгу Н. Гарифа «Освободительная война татарского народа». - Звезда Поволжья. № 26(477). 9-15 июля.

Измайлов Б.И., Бушуев А.С., Салихов Р.Р. 2009. Рецензия на книгу «Освободительная война татарского народа» (повторный анализ ученых-историков). - Звезда Поволжья. № 31(482). 20-26 августа.

Мороз О., Суверина Е. 2014. Trauma studies: История, репрезентация, свидетель. - Новое литературное обозрение. № 1(125). С. 59-74.

Николаи Ф.В. 2018. Полемика о травме и памяти в американской философии культуры: дис. ... д.филос.н. Нижний Новгород. 335 с.

Овчинников А.В. 2019. Личная психологическая и «народная» историческая травмы: опыт коллективного портрета автора этнонациональных историй Татарстана. - Творческая лаборатория историка: горизонты возможного (к 90-летию со дня рождения Б.Г. Могильницкого): материалы всероссийской науч- 
ной конференции с международным участием. Томск, 3-4 октября 2019 г.: в 2 ч. Томск: Изд-во Томского университета. Ч. 2. С 58-364.

Сагитова Л.В. 2019. Политика идентичности и ее акторы в условиях социальной трансформации в Республике Татарстан: дис. ... д.полит.н. Казань. 428 с.

Сафронова Ю.А. 2019. Культурная травма и культурная память. - Историческая память: введение: учебное пособие. СПб: Изд-во Европейского университета в Санкт-Петербурге. С. 122-144.

Тагиров И.Р. 2008. История национальной государственности татарского народа и Татарстана: научное издание. 2-е изд. Казань: Татарское книжное издательство. 454 с.

Тагиров И.Р. 2016. По жизненному пути. М.: Собрание. 470 с.

Ушакин С. 2009. «Нам этой болью дышать»? О травме, памяти и сообществах. - Tравма: пункты: сборник статей. М.: Новое литературное обозрение. С. 5-44.

Фахрутдинов Р.Г. 2018. История татар. Казань: Татарское книжное издательство. 104 с.

Фахрутдинов Р.Г. 2000. История татарского народа и Татарстана (Древность и Средневековье): учебник для средних общеобразовательных школ, гимназий и лицеев. Казань: Магариф. 255 с.

Фахрутдинов Р.Г., Фахрутдинов Р.Р. 2015. История татарского народа. Казань: Татарское книжное издательство. 407 с.

OVCHINNIKOV Aleksandr Viktorovich, Cand.Sci. (Hist.), Scientific Researcher of the Laboratory of Transdisciplinary Research of Cognition, Language, and Social Practices, Faculty of Philosophy, National Research Tomsk State University (36 Lenina Ave, Tomsk, Russia,634050; ovchinnikov8_831@mail.ru)

ERSHOVA Guzel' Nikolaevna, Cand.Sci. (Hist.), Lecturer of the Chair of State, Municipal Management and Sociology, Kazan National Research Technological University (68 Karla Marksa St, Kazan, Republic of Tatarstan, Russia, 420015; ershova104@mail.ru)

\title{
1552 IN THE NETWORK SOCIETY OF THE REPUBLIC OF TATARSTAN: SOCIAL AND POLITICAL ASPECTS OF THE VERSIONS OF THE HISTORICAL TRAUMA
}

\begin{abstract}
The relevance of the article is due to the need to collect empirical material for a philosophical understanding of the problem of historical traumas, as well as the practical importance of analyzing constructs that are opposed to images of the all-Russian identity. The object of the research is modern Tatar ethno-nationalism, the subject is the reflection within its framework of the capture of Kazan by Ivan IV in 1552. The authors used socio-cultural anthropology methods of observation, included experiment, and rich description. The scientific novelty of the work consists in an attempt to analyze the social and political aspects of the versions of the historical trauma of 1552.
\end{abstract}

Keywords: capture of Kazan, Memorial Day, Ivan IV, historical trauma, liberation war of the Tatar people, Tatar ethno-nationalism 